\title{
Gambaran histologi ovarium sapi Aceh pascavitrifikasi menggunakan dimetyl sulfoksida dengan konsentrasi berbeda
}

\author{
Syafruddin ${ }^{1}$, Arman Sayuti ${ }^{1}$, Rahmat Aditya Sumardi ${ }^{2}$, Budianto Panjaitan ${ }^{1} *$ \\ ${ }^{1}$ Laboratorium Klinik, Fakultas Kedokteran Hewan, Universitas Syiah Kuala, Banda Aceh \\ ${ }^{2}$ Program Studi Pendidikan Dokter Hewan, Fakultas Kedokteran Hewan, Universitas Syiah Kuala, Banda Aceh
}

\begin{abstract}
This study aims to determine the morphology of Aceh bovine ovarian pasca vitrification, after its been exposed to dimetyl sulfoksida (DMSO) cryoprotectant. This study use a completely randomized design of one-way pattern ANOVA acquire three replications. Ovaries used in this study are Aceh cattle ovarian which collected from slaughter house (RPH) accounted as 4 organs, to the next sliced into 9 pieces. Ovarian pieces are then grouped into 3 treatment groups namely ovaries which exposed into solution containing DMSO 10\% (P1), 20\% (P2), and 30\% (P3). The results showed that the average number of normal follicles is highest at P1 41,33 $\pm 32,51$; followed by P2 20,00 $\pm 16,09$, and P3 15,66 $\pm 10,50$. It was concluded that the ovarian tissue was exposed with DMSO $10 \%$ was able to maintain of the normal follicle than DMSO $20 \%$ and $30 \%$ although statistical test results showed no significant difference between group $(\mathrm{P}>0,05)$.

Keywords:

ovary, cryopreservation, vitrification, cryoprotectant, histology
\end{abstract}

\section{- PENDAHULUAN}

Salah satu upaya untuk mengatasi ancaman kepunahan sapi aceh adalah melalui produksi embrio menggunakan teknologi fertilisasi in vitro (IVF). Teknologi IVF saat ini, masih memanfaatkan oosit segar dengan daya tahan hidup yang sangat terbatas sehingga tidak dapat disimpan dalam waktu yang lama pada suhu kamar (Vieira et al., 2002).

Waktu simpan yang terbatas dapat diatasi melalui penyimpanan beku (kriopreservasi) pada oosit atau ovarium. Terdapat 2 metode kriopreservasi yaitu metode konvensional dan vitrifikasi (Wahjuningsih et al., 2010). Kelebihan dari metode vitrifikasi adalah proses pemadatan cairan tanpa disertai dengan terbentuknya kristal es (Shaw et al., 2000). Krioprotektan selain dapat melindungi sel, bahan tersebut juga dapat menimbulkan kerusakan karena sifat toksisitasnya terhadap sel (Kasai, 2002). Krioprotektan yang umum digunakan adalah dimetyl sulfoksida (DMSO), etylen glikol, gliserol, dan propilen glikol. Penelitian kemudian memelajari pengaruh DMSO dalam proses vitrifikasi ovarium sapi Aceh secara histologi.

\section{- MATERI DAN METODE}

Ovarium: Ovarium sapi Aceh sebanyak 4 buah diperoleh dari rumah potong hewan (RPH) Lambaro, Aceh Besar.

Vitrifikasi Ovarium: Vitrifikasi ovarium dilakukan seperti metode vitrifikasi sel telur (Djuwita et al., 2000). Ovarium dipotong menjadi 9 bagian. Ovarium dipaparkan secara berurutan dalam larutan Phosphate Buffer Solution (PBS) + sukrosa 0,25 M; PBS + sukrosa 0,5 M; PBS + sukrosa 0,5 $\mathrm{M}+$ krioprotektan DMSO 10\%; dan PBS + sukrosa 0,5 M + krioprotektan DMSO 10\%, 20\%, dan 30\% selama 5 menit pada masing-masing perlakuan. Ovarium kemudian dikemas dalam pipet (straw), selanjutnya dipaparkan pada uap nitrogen cair selama 10 detik dan langsung dimasukkan kedalam nitrogen cair. Ovarium di dalam nitrogen cair selama 30 menit. Straw diambil dari nitrogen cair, dibiarkan di udara selama 10 detik lalu dimasukkan kedalam air dengan suhu $37{ }^{\circ} \mathrm{C}$ sampai mencair. Straw dipotong, ovarium dikeluarkan dan dimasukkan berturut-turut kedalam larutan PBS + sukrosa 0,5 M; PBS + sukrosa 0,25 M; dan PBS (3 kali) masing-masing selama 5 menit.

Pembuatan Preparat Histologis: Jaringan ovarium yang dikoleksi kemudian difiksasi dalam larutan paraformaldehid 4\% selama 4 hari. Jaringan kemudian didehidrasi dalam alkohol, dijernihkan dalam xylol, dan ditanam dalam parafin. Jaringan dipotong secara serial pada ketebalan $5 \mu \mathrm{m}$. Preparat dideparafinisasi, direhidrasi, dan diwarnai menggunakan pewarna hematoksilin-eosin (HE).

Analisis Data: Data diuji secara statistik mengunakan program SPSS 16,0 for Windows dan dilanjutkan dengan uji Duncan's Multiple Range Test (Steel \& Torrie, 1993).

\section{- HASIL DAN PEMBAHASAN}

Hasil penelitian menunjukkan jumlah folikel utuh pada setiap kelompok perlakuan tidak berbeda nyata $(\mathrm{P}>0,05)$.

Diterima: 31-10-2018 | Direvisi: 21-11-2018 | Disetujui: 26-11-2018

(C) 2018 CC-BY-SA. Ini adalah artikel Open Access yang didistribusikan berdasarkan ketentuan dari Creative Commons Attribution ShareAlike 4.0 International License (https://creativecommons.org/licenses/by-sa/4.0/). 
Hasil pemeriksaan jumlah folikel utuh pada setiap kelompok perlakuan penggunaan konsentrasi DMSO 10\%, 20\%, dan 30\% ditampilkan pada Tabel 1 .

Tabel 1 Jumlah folikel yang utuh pada jaringan ovarium setelah divitrifikasi kedalam $\mathrm{N}_{2}$ cair

\begin{tabular}{|c|c|}
\hline Kelompok & Jumlah Folikel Utuh \\
\hline P1 (DMSO 10\%) & $41,33 \pm 32,51^{\mathrm{a}}$ \\
\hline P2 (DMSO 20\%) & $20,00 \pm 16,09^{\mathrm{a}}$ \\
\hline P3 (DMSO 30\%) & $15,66 \pm 10,50^{\mathrm{a}}$ \\
\hline
\end{tabular}

${ }^{a}$ superskrip yang sama pada kolom yang sama menunjukkan tidak berbeda nyata $(\mathrm{P}>0,05)$

Jumlah folikel utuh dapat diamati melalui pewarnaan HE dan dapat diketahui bahwa folikel primer mempunyai selapis sel granulosa yang berbentuk kuboid, folikel sekunder mempunyai dua lapis sel granulosa dan folikel tersier mempunyai lebih dari 2 lapis sel granulosa dan memiliki antrum. Jumlah folikel utuh tertinggi pada konsentrasi DMSO 10\%, sedang jumlah folikel utuh terendah pada konsentrasi DMSO 30\%. Jumlah folikel utuh yang terdapat pada konsentrasi DMSO 10\% tidak berbeda nyata dibandingkan dengan jumlah folikel utuh pada konsentrasi $20 \%$ dan 30\% ( $\mathrm{P}>0,05)$.

\section{Morfologi Folikel Setelah Divitrifikasi}

Semua perlakuan ditemukan folikel dengan morfologi normal dan tidak normal. Kerusakan yang terjadi pada ovarium berupa pecahnya sel-sel folikel, piknotik inti sel telur, kerobekan sel-sel granulosa, dan oosit. Kerusakan morfologi yang sering terjadi adalah pecahnya zona pelusida, desintegrasi membran plasma, kerusakan bahan serta organel sitoplasma seperti skeleton sel, kromosom, butir-butir korteks, dan butir-butir lemak (Fukui et al., 1993). Morfologi folikel primer utuh dan folikel primer yang mengalami pengkerutan disajikan pada Gambar 1 .

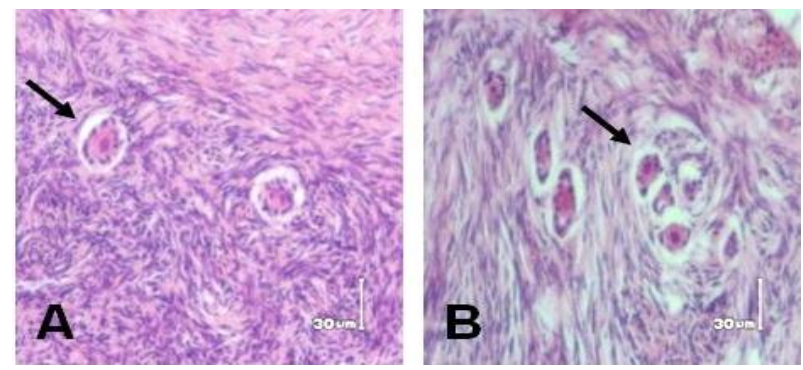

Gambar 1 Perwarnaan HE folikel primer dengan morfologi utuh (A) dan folikel yang mengalami pengkerutan (krenasi) (B).

Proses vitrifikasi menurunkan persentase folikel normal. Integritas morfologi sejumlah besar folikel-folikel preantral secara keseluruhan dapat dipertahankan selama proses vitrifikasi. Proses penetrasi krioprotektan melalui sel-sel stroma menuju oosit sangat diperlukan dalam proses vitrifikasi, namun pada saat yang sama harus dipertimbangkan adanya efek toksisitas dari krioprotektan yang digunakan (Donnez et al., 2006). Newton et al. (1998) melaporkan bahwa laju dan suhu difusi berpengaruh terhadap toksisitas krioprotektan, pembentukan kristal es juga harus diminimalkan dengan memilih laju pembekuan dan thawing optimal.
DMSO digunakan karena memiliki kapasitas penetrasi yang baik dan toksisitas yang lebih kecil dibandingkan krioprotektan lainnya pada jaringan ovarium (Lucci et al., 2007). Penggunaan DMSO dengan konsentrasi $10 \%$ mampu mempertahankan keutuhan morfologi folikel dibandingkan dengan konsentrasi $20 \%$ dan $30 \%$. Hal ini sesuai dengan pendapat Pamungkas (2010), bahwa semakin tinggi laju pendinginan semakin rendah krioprotektan yang diperlukan.

\section{SIMPULAN}

Penambahan bahan DMSO pada media tidak berpengaruh terhadap jumlah folikel utuh pada ovarium sapi Aceh yang dibekukan dengan metode vitrifikasi $(\mathrm{P}>0,05)$. Rataan folikel utuh tertinggi adalah pada konsentrasi DMSO $10 \%$.

\section{- INFORMASI PENULIS}

Penulis untuk Korespondensi

*BP: budi@unsyiah.ac.id

Laboratorium Klinik Fakultas Kedokteran Hewan Universitas Syiah Kuala, Banda Aceh

\section{- PUSTAKA ACUAN}

Djuwita I, Boediono A, Rusiyantono Y, Mohamad K, Herliatien. 2000. Perkembangan oosit kambing setelah maturasi, fertilisasi dan kultur in vitro. Media Veteriner. 7(4):11-17.

Donnez J, Martinez-Madrid B, Jadoul P, Van Langendonckt A, Demylle D. 2006. Ovarian tissue cryopreservation and transplantation: a review. Hum. Reprod. Update. 12(5):519-535.

Fukui EJ, Xia L, Downey BR. 1993. Ultrastructural changes in bovine oocyte cryopreserved by vitrification. Cryobiology. 32(2):139-156.

Kasai M. 2002. Advances in the cryopreservation of mammalian oocytes and embryos: development of ultra rapid vitrification. Rev. 1:1-9.

Lucci CM, Scheier LL, Machado GM, Amorim CA, Bao SN. 2007. Effect of storing pig ovaries at 4 or $20^{\circ} \mathrm{C}$ for different periods of time on the morfology and viability of pre-antra follicles. Reprod. Dom. Anim. 42:76-82.

Newton H, Fisher J, Arnold JR, Pegg DE, Faddy MJ, Gosden RG. 1998. Permeation of human ovarian tissue with cryoprotective agents in preparation for cryopreservation. Hum. Reprod. 13:376-380.

Pamungkas FA. 2010. Pemanfaatn metode vitrifikasi untuk kriopreservasi oosit mamalia. Wartazoa. 20(3):112-116.

Shaw JM, Oranratnachai A, Trounson AO. 2000. Fundamental cryobiology of mammalian oocytes and ovarian tissue. Theriogenology. 53:59-72.

Steel RGD, Torrie JH. 1993. Prinsip dan Prosedur Statistik. (Diterjemahkan oleh: Soemantri). Gramedia: Jakarta.

Vieira AD, Mezzalira A, Barbieri DP, Lehmkuhl RC, Rubin MIB, Vajta G. 2002. Calves born after open pulled straw vitrification of immature bovine oocytes. Cryobiology. 45:91-94.

Wahjuningsih S, Hardjopranjoto S, Sumitro SM. 2010. Pengaruh konsentrasi etilen glikol dan lama paparan terhadap tingkat fertilitas in vitro oosit sapi. Jurnal Kedokteran Hewan. 4(2):6164. 